\title{
Evaluation of Activation and Inflammatory Activity of Myeloid Cells During Pathogenic Human Coronavirus Infection
}

\author{
Rudragouda Channappanavar and Stanley PerIman
}

\begin{abstract}
Innate immune cells play a vital role in mounting an effective host response to a variety of pathogen challenges. Myeloid cells such as neutrophils and monocyte-macrophages are major innate leukocytes that orchestrate protective immunity to viral lung infections. However, a dysregulated cytokine response can promote excessive infiltration and robust pro-inflammatory activity of neutrophils and monocytemacrophages, leading to fatal disease. Following virus infection, the beneficial or deleterious role of infiltrating neutrophils and monocyte-macrophages is determined largely by their ability to secrete inflammatory cytokines and chemokines. A majority of studies use the total number of infiltrating cells and their activation status as measures to demonstrate their role during an infection. Consequently, the ability of neutrophils and Inflammatory Monocyte Macrophages (IMMs) to secrete inflammatory cytokines and chemokines, and its correlation with the disease severity, is not well defined. In this chapter, we report useful markers to identify lung infiltrating innate immune cells and define their activation status. We also describe a simple method to measure intracellular cytokine production to evaluate the inflammatory activity of neutrophils and IMMs in a mouse model of human coronavirus infection.
\end{abstract}

Key words Coronavirus, Neutrophils, Inflammatory monocyte-macrophages, Lungs, Cytokines and chemokines

\section{Introduction}

Myeloid cells such as neutrophils and monocyte-macrophages are key immune cells that make up a large proportion of tissue infiltrating innate leukocytes following a pathogen challenge. Both neutrophils and inflammatory monocytes-macrophages (IMMs) are rapidly recruited to the site of infection and play crucial roles in the host defense against viral lung infections $[1,2]$. The antiviral functions of neutrophils and monocyte-macrophages are facilitated following the recognition of pathogen-associated molecular patterns (PAMPs) by the cell surface and endosomal toll-like receptors (TLRs) and intracellular RIG-I like (RLRs) and Nod-like receptors 
(NLRs). Detection of viral PAMPs (viral proteins and nucleic acids) by these sensors leads to the activation of a cascade of signaling events resulting in the production of antiviral molecules like interferons (IFNs), interferon-stimulated genes (ISGs), and inflammatory cytokines and chemokines [3-5]. IMMs and neutrophils also participate in the phagocytosis of virus-infected cells and orchestrate effective adaptive $\mathrm{T}$ cell responses, both of which are essential for effective virus clearance [6].

In addition to host protective function of myeloid cells during viral lung infections, several recent studies demonstrate their role in mediating cytokine storm and thus exacerbating the host immune response to virus infections [2,7]. The deleterious functions of neutrophils and IMMs are linked to dysregulated type I IFN (IFN-I) responses, particularly during high pathogenic virus infections $[8,9]$. For example, while a controlled neutrophil response is protective during influenza A virus infection, an excessive neutrophil accumulation is detrimental $[10,11]$. Similarly, an exaggerated monocyte-macrophage response resulting from delayed IFN-I signaling is detrimental during human coronavirus infections [8]. IMMs and neutrophils also express increased levels of death receptors such as DR5 and FAS, and the interaction of these receptors with their ligands TRAIL and FASL, respectively, promotes airway epithelial and lung microvascular endothelial cell death $[9,12,13]$. Additionally, excessive inflammatory cytokines and chemokines produced by IMMs and neutrophils impair antiviral $\mathrm{T}$ cell responses, leading to ineffective virus clearance and reduced survival [8].

A majority of the studies demonstrating the beneficial or detrimental effects of neutrophils and IMMs during viral lung infections enumerate percentages and total number and define activation status of the lung infiltrating myeloid cells using surface markers [14]. We recently showed spontaneous production of several inflammatory cytokines and chemokines by neutrophils and IMMs, which correlated with severe lung pathology and reduced survival in CoV infections [8]. Thus, the identification of specific inflammatory cytokines and chemokines produced by these cells will allow us to define their pro-inflammatory status and design strategies to control inflammatory responses. In this study, we describe useful markers to identify innate immune cells infiltrating into the lung and describe a simple method to evaluate inflammatory cytokine and chemokine production by neutrophils and monocyte-macrophages during pathogenic human coronavirus infections. 


\section{Materials}

\subsection{Infection}

\subsection{Harvesting Lungs}

\subsection{Digestion and Processing of Lung Tissue}

\subsection{Incubation and/ or Stimulation of Lung Cells for Intracellular Cytokine Staining}

\subsection{FACS Staining and Acquisition}

1. Sterile, endotoxin-free, pharmaceutical grade physiological saline, $1 \times$ phosphate-buffered saline, or $1 \times$ Dulbecco's Modified Minimum Essential Medium.

2. Isoflurane, isoflurane vaporizer and induction chamber or cocktail of xylazine $(12.5 \mathrm{mg} / \mathrm{kg})+$ ketamine $(85 \mathrm{mg} / \mathrm{kg})$.

3. $1 \mathrm{~mL}$ syringe for anesthetic administration.

4. Sterile $200 \mu \mathrm{L}$ pipette tips and single channel $200 \mu \mathrm{L}$ pipette.

5. Human coronavirus aliquots.

1. Anesthetic-ketamine $(85 \mathrm{mg} / \mathrm{kg})+$ xylazine $(12.5 \mathrm{mg} / \mathrm{kg})$.

2. $1 \mathrm{~mL}$ syringe for anesthetic administration and $10 \mathrm{~mL}$ syringe for lung perfusion.

3. Surgical equipment (scissors, forceps, 22G 5/7 needles).

4. $\mathrm{I} \times$ PBS or pharmaceutical grade physiological saline and $22 \mathrm{G}$ $5 / 7$ needles

5. Square (6-12 inch) styrofoam or cardboard, absorbent pads.

1. Scissors and forceps.

2. A 12-well plate for mincing lung tissue.

3. Lung digestion DNAse I/Collagenase D buffer.

4. $15 \mathrm{~mL}$ and $50 \mathrm{~mL}$ conical tubes.

5. Tube rotator.

6. Six-well plates for homogenizing lung tissue.

7. $3 \mathrm{~mL}$ syringe plunger, plastic Pasteur pipettes $(3 \mathrm{~mL})$.

8. RPMI 10\% FBS media.

9. Benchtop lab centrifuge with rotors and cups to hold $15 \mathrm{~mL}$ or $50 \mathrm{~mL}$ conical.

1. 96-well plates, $200 \mu \mathrm{L}$ multichannel pipette, $200 \mu \mathrm{L}$ single channel pipette

2. RPMI 10\% FBS, and Golgi-plug.

3. TLR ligands: Poly I:C, LPS, and R837.

1. 96-Well plates.

2. FACS buffer (PBS+ 2-5\% FBS+0.01\% sodium azide).

3. Cytofix/Cytoperm buffer.

4. Perm/Wash Buffer.

5. Antibodies: anti-mouse CD45 PE-Cy7 (Clone: 30-F11), antimouse CDllb e450 Cat (Clone: $\mathrm{Ml} / 70$ ), anti-mouse CDl lc 
PE (Clone: N418), anti-mouse IA/IE PerCp-Cy5.5 (clone: M5/114.15.2), anti-mouse Ly6C percp-cy5.5 (Clone: HKl.4), anti-mouse Ly6G FITC (Clone:1A8,), anti-mouse TNF APC (Clone: MP6-XT22), anti-mouse IL-6 APC (Clone:MP5-20F3), anti-mouse iNOS APC (Clone: CXNFT), anti-mouse IL-1 $\beta$ APC (Clone: NJTEN3), antimouse CD80 APC (Clone: 16-10Al), anti-mouse CD86 APC (Clone:GL-1 $\backslash$ ), anti-mouse CD69 APC (Clone: H1.2F3), anti-mouse PDCA-l PE/APC (Clone:JF051C2.4.1), and anti-mouse CD16/32 (clone: 2.4G2).

6. Flow Cytometer (capable of detecting six or more fluorophores).

\section{Methods}

\subsection{Mice Infection}

\subsection{Harvesting and Digestion of Lungs}

1. Thaw a virus aliquot on ice just before infection, avoiding repeated freeze-thaw.

2. Dilute MERS-CoV and SARS-CoV in DMEM to achieve the required dose and keep virus on ice throughout the infection time (see Note $\mathbf{1})$.

3. Under xylazine/ketamine anesthesia (confirmed by pedal reflex), slowly deliver $40-50 \mu \mathrm{L}$ of a well-mixed virus inoculum directly into the nostrils using a $200 \mu \mathrm{L}$ pipette (see Note 2 ).

4. Following virus delivery, mouse should be placed on its dorsal side in a cage with bedding for the remaining virus inoculum to be inhaled.

5. Monitor mice every $10 \mathrm{~min}$ until complete recovery.

1. On days 4-5 post-infection, under complete xylazine/ketamine or isoflurane anesthesia (confirmed by pedal reflex), cut open the abdominal cavity to expose the diaphragm. Make an incision through the diaphragm with scissors, remove diaphragm, and then remove the rib cage to completely expose the heart and lungs ( see Note 3 ).

2. Fill a $10 \mathrm{~mL}$ syringe with ice-cold sterile PBS and attach a $25 \mathrm{G} \times 5 / 8$ needle. Insert the needle into the right ventricle of the heart and slowly inject $5 \mathrm{~mL}$ of DPBS into the heart. In the meantime, use forceps to break the left atria to allow blood to drain from circulation. Inject remaining $5 \mathrm{~mL}$ of DPBS until lungs turn pale.

3. Separate the heart and then remove the lung from the thoracic cavity. Separate and discard any remaining connective tissue associated with the lungs (see Note 4).

4. Place the lungs into the well of a 12 -well tissue culture plate filled with $2.5 \mathrm{~mL}$ of DPBS on ice. 
5. Rinse the lungs with DPBS and transfer it into another well without DPBS. Mince the lungs into very fine pieces using scissors.

6. Transfer minced lungs with a $2.5 \mathrm{~mL}$ plastic transfer pipette to a $15 \mathrm{~mL}$ conical tube containing $5 \mathrm{~mL}$ of digestion buffer.

7. Place tubes on a rocker and gently rock at room temperature for $30 \mathrm{~min}$ ( see Note 5 ).

8. Place a $70 \mu \mathrm{m}$ cell strainer in a $60 \times 15 \mathrm{~mm}$ tissue culture dish or in a well of a 6-well plate.

9. Transfer lung tissue in digestion buffer on to the cell strainer using a $2.5 \mathrm{~mL}$ transfer pipette. Gently press and dissociate tissue through a strainer with the flat end of a $3 \mathrm{~mL}$ syringe plunger. Process tissues until there is only connective tissue remaining on the strainer and rinse the strainer with complete RPMI 1640 medium.

10. Spin down lung cells in $15 \mathrm{~mL}$ conical tube for $5 \mathrm{~min}$ at $300 \times g$ at $4{ }^{\circ} \mathrm{C}$ in a bucket tabletop centrifuge.

11. Discard off supernatant and resuspend the cells in $1 \mathrm{~mL}$ of ACK buffer for 1 min to lyse the remaining red blood cells. Neutralize the ACK buffer with $10 \mathrm{~mL}$ of ice-cold DPBS or $10 \mathrm{~mL}$ of $5 \%$ RPMI medium.

12. Spin down the cells for $5 \mathrm{~min}$ at $300 \times g$ at $4{ }^{\circ} \mathrm{C}$ and resuspend the cells in $5 \mathrm{~mL}$ of ice-cold buffer.

3.3 Cell Surface Staining for Innate Immune Cells (See Note 6)
1. Spin down lung cells for $5 \mathrm{~min}$ at $300 \times g$ at $4{ }^{\circ} \mathrm{C}$.

2. Dilute $0.2 \mu \mathrm{g}$ of CD16/32 antibodies in $100 \mu \mathrm{L}$ FACS buffer and resuspend cells in FACS buffer containing CDI6/32 antibodies in a 96-well plate.

3. Gently mix the cells and antibodies.

4. Incubate the cells in the dark for $15 \mathrm{~min}$ at $4{ }^{\circ} \mathrm{C}$.

5. Wash the cells twice with $150 \mu \mathrm{L}$ of FACS buffer at $300 \times g$ for 5 min at $4{ }^{\circ} \mathrm{C}$.

6. Resuspend the cells in $100 \mu \mathrm{L}$ FACS buffer containing the antibody cocktail.

7. Incubate the cells in the dark for $20 \mathrm{~min}$ at $4{ }^{\circ} \mathrm{C}$.

8. Spin down lung cells for $5 \mathrm{~min}$ at $300 \times g$ at $4{ }^{\circ} \mathrm{C}$ and discard the FACS buffer.

9. Wash the cells twice with $150 \mu \mathrm{L}$ of FACS buffer at $300 \times g$ for 5 min at $4{ }^{\circ} \mathrm{C}$.

10. Resuspend the cells in $200 \mu \mathrm{L}$ of FACS buffer and acquire using a flow cytometer.

11. Figure 1 provides an example of IMM activation marker expression in $\mathrm{CoV}$ infected lungs. 


\section{Gated on CD45+ CD11 b+ Ly6Chi lung cells}
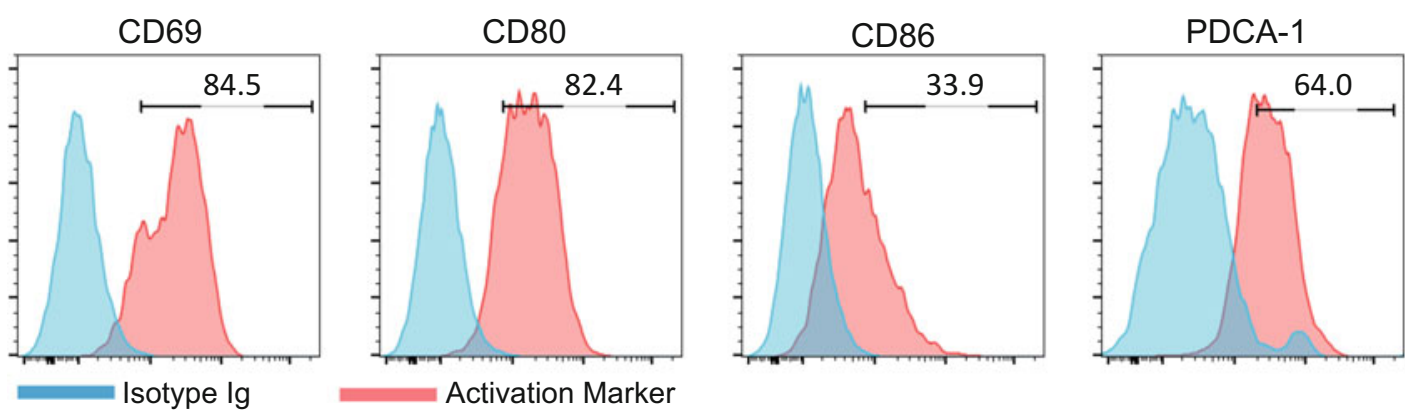

Fig. 1 Ideal markers to determine activation status of IMMs. Lung cells harvested from SARS-CoV-infected $\mathrm{BALB} / \mathrm{c}$ mice ( $3 \mathrm{dpi}$ ) were surface stained for IMMs and activation markers as described in the methods section

\subsection{Incubation and or Stimulation of Lung Cells for Intracellular Cytokine Staining (See Note 7)}

1. Count live cells using a hemocytometer by staining with trypan blue.

2. Spin down lung cells for $5 \mathrm{~min}$ at $300 \times g$ at $4{ }^{\circ} \mathrm{C}$ and resuspend the cells in RPMI 10\% FBS at one million cells per $100 \mu \mathrm{L} /$ well.

3. Dispense $100 \mu \mathrm{L}$ of cells into a well of 96 -well plates and add additional $100 \mu \mathrm{L}$ RPMI 10\% FBS media with or without Golgi-plug ( $1 \mu \mathrm{g} / \mathrm{mL}$ ) with or without a TLR agonist (LPS 10-100 ng/mL, R837 and Poly I:C $100 \mathrm{ng}$ to $1 \mu \mathrm{g} / \mathrm{mL}$ ).

4. Incubate cells for $6-7 \mathrm{~h}$ at $37^{\circ} \mathrm{C}$ in $\mathrm{CO}_{2}$ incubator.

5. After incubation, wash cells twice with RPMI 10\% FBS media.

1. Spin down lung cells for $5 \mathrm{~min}$ at $300 \times g$ at $4{ }^{\circ} \mathrm{C}$.

2. Dilute $0.2 \mu \mathrm{g}$ of CD16 antibodies in $100 \mu \mathrm{L}$ FACS buffer and resuspend cells in FACS buffer containing CD16/32 antibodies in a 96-well plate.

3. Gently mix the cells and antibodies.

4. Incubate the cells in the dark for $15 \mathrm{~min}$ at $4{ }^{\circ} \mathrm{C}$.

5. Wash the cells twice with $150 \mu \mathrm{L}$ of FACS buffer at $300 \times \mathfrak{g}$ for 5 min at $4{ }^{\circ} \mathrm{C}$.

6. Resuspend the cells in $100 \mu \mathrm{L}$ FACS buffer containing $0.25 \mu \mathrm{g}$ of cell surface identification and activation marker antibodies (see Table 1).

7. Incubate the cells in the dark for 20 min at $4{ }^{\circ} \mathrm{C}$.

8. Spin down lung cells for $5 \mathrm{~min}$ at $300 \times g$ at $4{ }^{\circ} \mathrm{C}$ and discard the FACS buffer.

9. Wash the cells twice with $150 \mu \mathrm{L}$ of FACS buffer at $300 \times \mathfrak{g}$ for 5 min at $4{ }^{\circ} \mathrm{C}$. 


\section{Table 1}

Cell surface markers to identify lung resident and lung infiltrating innate immune cells

\begin{tabular}{|c|c|c|}
\hline No. & Innate immune cell & FACS markers \\
\hline 1 & $\begin{array}{l}\text { Alveolar } \\
\text { macrophage }\end{array}$ & $\mathrm{CD} 45^{+} \mathrm{CD} 1 \mathrm{cc}^{+}$SiglecF ${ }^{+}$or $\mathrm{CD} 45^{+} \mathrm{CDIlc} \mathrm{c}^{+} \mathrm{F} 4 / 80^{+}$ \\
\hline 2 & Neutrophils & $\mathrm{CD}_{4} 5^{+} \mathrm{Ly} 6 \mathrm{C}^{\text {int }} \mathrm{Ly}_{6 \mathrm{G}^{+}}$or $\mathrm{CD} 45^{+} \mathrm{CD} 11 \mathrm{~b}^{+} \mathrm{Grl}^{+}$ \\
\hline 3 & Monocytes & $\mathrm{CD}_{4} 5^{+} \mathrm{CD} 11 \mathrm{~b}^{+} \mathrm{Ly}_{6 \mathrm{C}}{ }^{\mathrm{hi}} \mathrm{CCR} 2^{+}$ \\
\hline 4 & Macrophages & $\mathrm{CD} 45^{+} \mathrm{CD} 11 \mathrm{~b}^{+} \mathrm{F} 4 / 80^{+}$ \\
\hline 5 & Dendritic cells & $\mathrm{CD} 45^{+} \mathrm{CD} 1 \mathrm{lb}-\mathrm{CD} 1 \mathrm{c}^{+} \mathrm{MHC}-\mathrm{II}^{+}$ \\
\hline 6 & Natural killer cells & 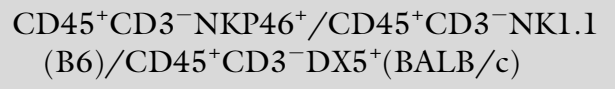 \\
\hline 7 & Eosinophils & $\mathrm{CD} 45^{+} \mathrm{CD} 1 \mathrm{lb}^{+} \mathrm{CDIll}^{-}$SiglecF $^{+}$ \\
\hline
\end{tabular}

10. Add $100 \mu \mathrm{L}$ of Cytofix/Cytoperm buffer and incubate cells in the dark for $25 \mathrm{~min}$ at $4{ }^{\circ} \mathrm{C}$.

11. Add another $100 \mu \mathrm{L}$ of $1 \times$ perm buffer (diluted to $1 \times$ with $\left.\mathrm{ddH}_{2} \mathrm{O}\right)$, spin down the cells $\left(400 \times g\right.$ for $5 \mathrm{~min}$ at $\left.4{ }^{\circ} \mathrm{C}\right)$, and discard the buffer.

12. Add $100 \mu \mathrm{L}$ of $1 \times$ perm buffer containing anti-cytokine antibodies. See Table 1 for markers and concentrations.

13. Incubate the cells in the dark for $25-30 \mathrm{~min}$ at $4{ }^{\circ} \mathrm{C}$.

14. After incubation add another $100 \mu \mathrm{L}$ of $1 \times$ perm buffer (diluted to $\mathrm{l} \times$ with $\left.\mathrm{ddH}_{2} \mathrm{O}\right)$, spin down $(400 \times g$ for $5 \mathrm{~min}$ at $4{ }^{\circ} \mathrm{C}$ ) the cells, and discard the buffer.

15. Wash the cells twice with $200 \mu \mathrm{L}$ of $1 \times$ perm buffer at $400 \times g$ for $5 \mathrm{~min}$ at $4{ }^{\circ} \mathrm{C}$.

16. Wash the cells once with $200 \mu \mathrm{L}$ of FACS buffer at $300 \times g$ for $5 \mathrm{~min}$ at $4{ }^{\circ} \mathrm{C}$ ( see Note 9 ).

17. Resuspend cells in $200 \mu \mathrm{L}$ of FACS buffer for FACS acquisition.

18. Acquire FACS data using a flow cytometer and analyze data using FlowJo software (see Note 10).

19. Figure 2 demonstrates intracellular inflammatory cytokine production by lung IMMs on day 1 and 3 post-SARS-CoV infection.

20. Figure 3 demonstrates intracellular cytokine production by IMMs and neutrophils following brief TLR stimulation. 

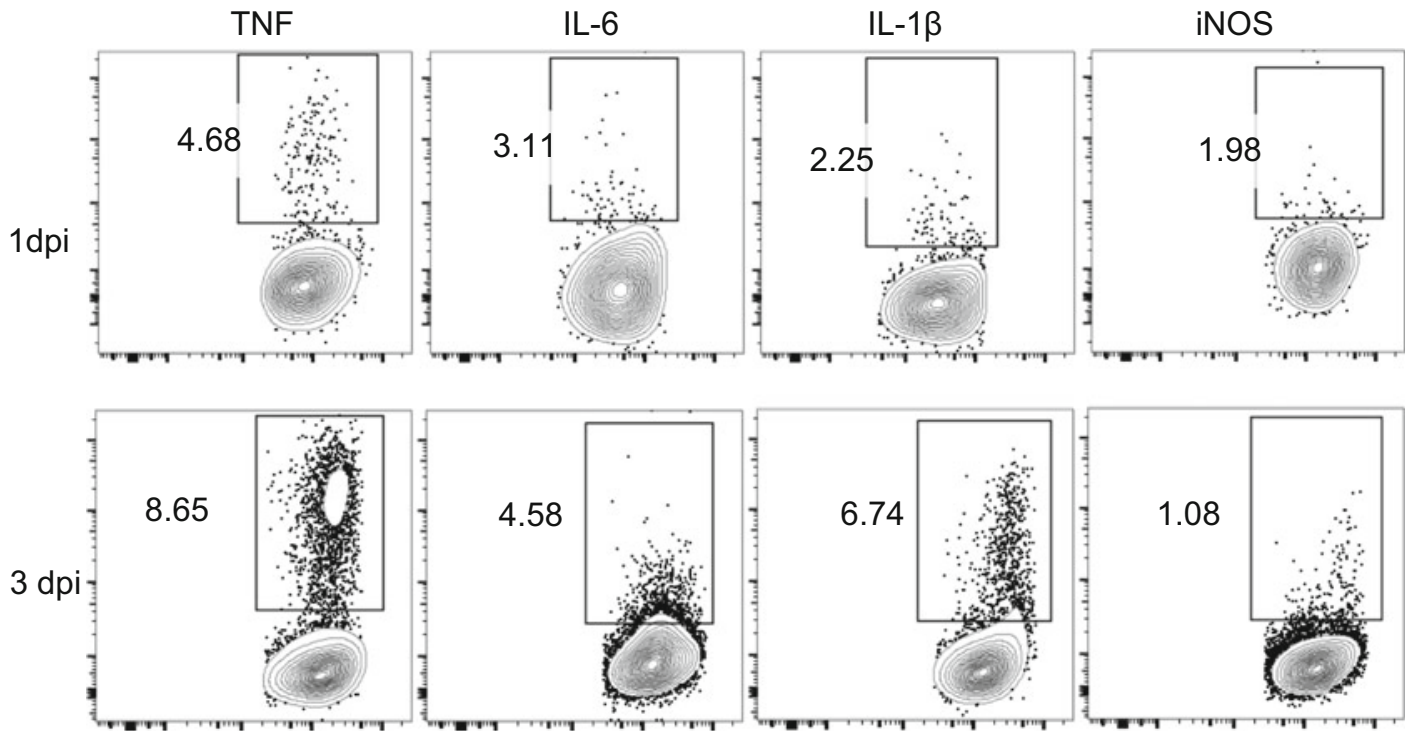

Fig. 2 Spontaneous cytokine production by IMMs. Lung cells isolated from SARS-CoV-infected BALB/c mice (1-3 dpi) were incubated for 7-h in the presence of Golgi-plug. Cells were then surface stained for IMMs $\left(C D 45^{+} C_{11} b^{+} L_{6 C} C^{\text {hi }}\right)$ and then for intracellular cytokines TNF, IL-6, IL-1 $\beta$, and iNOS
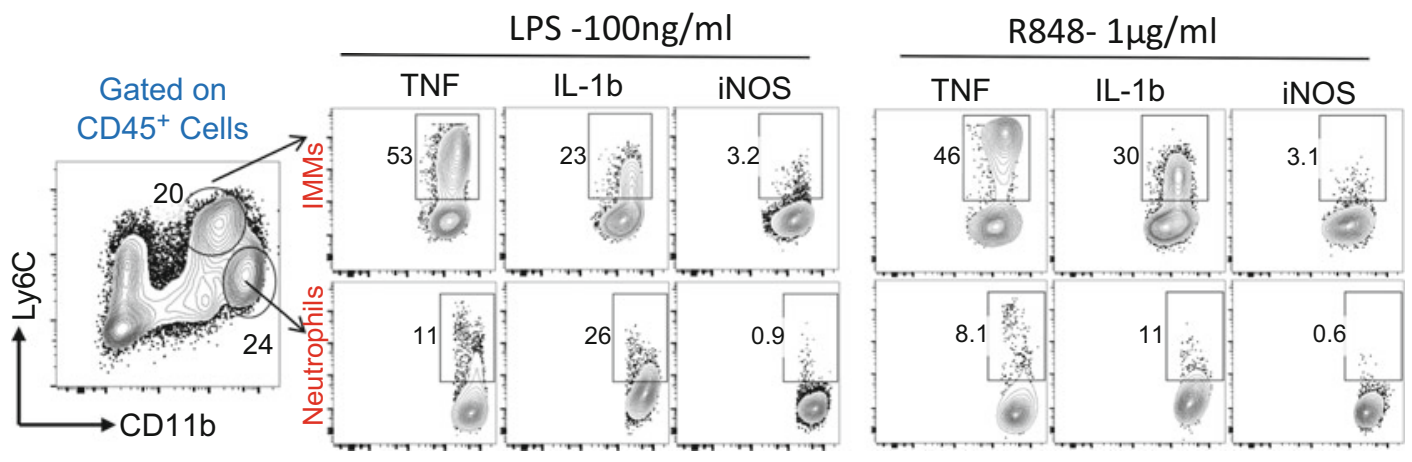

Fig. 3 Staining for intracellular cytokines in TLR-stimulated IMMs and neutrophils: Total lung cells isolated from SARS-CoV-infected BALB/c mice (3 dpi) were stimulated with LPS (TLR4 ligand, $100 \mathrm{ng} / \mathrm{mL}$ ) or R848 (TLR7 ligand, $1 \mu \mathrm{g} / \mathrm{mL}$ ) for $4-\mathrm{h}$ in the presence of Golgi-plug. IMMs (CD11b $\mathrm{b}^{\mathrm{hi}}$ Ly6 $\mathrm{c}^{\mathrm{hi}}$ ) and neutrophils $\left(C D 11 b^{\text {hi }}\right.$ Ly6C $\left.^{\text {int }}\right)$ were stained for intracellular TNF, IL-1 $\beta$, and iNOS production

\section{Notes}

1. Both MERS-CoV and SARS-CoV should be aliquoted in ice-cold DMEM and the media should be kept on ice throughout the period of infection.

2. Ketamine/xylazine anesthesia gives uniform infection compared to isoflurane. It is essential to make sure that the animals 
are completely anesthetized. Following anesthesia mice should be placed on their back on thick bedding to avoid hypothermia.

3. During MERS-CoV and SARS-CoV infection, neutrophil accumulation peaks between day 1 and 3 post-infection and monocytes between day 2 and 4 post-infection. As a result, days 2-4 are ideal time points to assess the activation and pro-inflammatory activity of myeloid cells.

4. Soon after harvesting, lungs should be placed in PBS on ice until further processed. Post-homogenization, the lung tissue can be digested at room temperature from 30 to $45 \mathrm{~min}$.

5. After Collagenase/DNAse digestion, the lung tissue in $15 \mathrm{~mL}$ conical should be kept on ice until further processed. Following tissue homogenization, all washing and cell surface staining should be carried out on the ice or at $4{ }^{\circ} \mathrm{C}$.

6. For efficient staining, antibodies should be diluted in $100 \mu \mathrm{L}$ of FACS buffer and added to assigned well of 96-well roundbottom plate or tube. Both plate and tubes should be placed on flat surface of vortex machine (with very low speed) to ensure that cell pellet is broken and antibody solution is uniformly distributed.

7. The concentration of LPS for stimulation should be 10-100 ng/mL. Other TLR agonists could be used at $1 \mu \mathrm{g} /$ $\mathrm{mL}$ concentration for optimum results. When adding TLR agonists and Golgi-plug, it is essential to dilute these reagents in RPMI-10 and add $100 \mu \mathrm{L}$ (of $2 \times$ concentration) to $100 \mu \mathrm{L}$ of cell suspension in the 96-well round-bottom plate. Alternatively, a $200 \mu \mathrm{L}$ of RPMI-10 media with TLR agonists and Golgi-plug (both at $1 \times$ concentration) can be added to the wells.

8. Intracellular cytokine staining (ICS) should be carried out using anti-mouse antibodies conjugated with APC or PE or PerCPcy5.5 dyes for better results and use other dyes accordingly for cell surface staining. For ICS staining, cells should be incubated for 25-30 min for better results. Keep cells on ice throughout cell surface and intracellular staining.

9. After surface staining, the cells should be treated with cytofix for $15 \mathrm{~min}$ followed by washing and resuspension in FACS buffer. There is no need to add cytofix to ICS-stained cells as these cells were already treated with Cytofix/Cytoperm buffer immediately before ICS staining.

10. For best results, cells should be acquired in flow cytometer within 1-2 days post-staining. 


\section{References}

1. Shi C, Pamer EG (2011) Monocyte recruitment during infection and inflammation. Nat Rev Immunol 11(11):762-774. https://doi. org $/ 10.1038 /$ nri3070

2. Camp JV, Jonsson CB (2017) A role for neutrophils in viral respiratory disease. Front Immunol 8:550. https://doi.org/10.3389/ fimmu.2017.00550

3. Hayashi F, Means TK, Luster AD (2003) Tolllike receptors stimulate human neutrophil function. Blood 102(7):2660-2669. https:// doi.org/10.1182/blood-2003-04-1078

4. Prince LR, Whyte MK, Sabroe I, Parker LC (2011) The role of TLRs in neutrophil activation. Curr Opin Pharmacol 11(4):397-403. https://doi.org/10.1016/j.coph.2011.06. 007

5. Malmgaard L, Melchjorsen J, Bowie AG, Mogensen SC, Paludan SR (2004) Viral activation of macrophages through TLR-dependent and -independent pathways. J Immunol 173 (11):6890-6898

6. Hashimoto Y, Moki T, Takizawa T, Shiratsuchi A, Nakanishi Y (2007) Evidence for phagocytosis of influenza virus-infected, apoptotic cells by neutrophils and macrophages in mice. J Immunol 178(4):2448-2457

7. Gralinski LE, Sheahan TP, Morrison TE, Menachery VD, Jensen K, Leist SR, Whitmore A, Heise MT, Baric RS (2018) Complement activation contributes to severe acute respiratory syndrome coronavirus pathogenesis. MBio 9(5). https://doi.org/10. $1128 / \mathrm{mBio} .01753-18$

8. Channappanavar R, Fehr AR, Vijay R, Mack M, Zhao J, Meyerholz DK, Perlman S (2016) Dysregulated type I interferon and inflammatory monocyte-macrophage responses cause lethal pneumonia in SARS-CoV-infected mice. Cell Host Microbe 19(2):181-193. https://doi. org/10.1016/j.chom.2016.01.007
9. Davidson S, Crotta S, McCabe TM, Wack A (2014) Pathogenic potential of interferon alphabeta in acute influenza infection. Nat Commun 5:3864. https://doi.org/10.1038/ ncomms 4864

10. Tate MD, Deng YM, Jones JE, Anderson GP, Brooks AG, Reading PC (2009) Neutrophils ameliorate lung injury and the development of severe disease during influenza infection. J Immunol 183(11):7441-7450. https://doi. org/10.4049/jimmunol.0902497

11. Brandes M, Klauschen F, Kuchen S, Germain RN (2013) A systems analysis identifies a feedforward inflammatory circuit leading to lethal influenza infection. Cell 154(1):197-212. https://doi.org/10.1016/j.cell.2013.06.013

12. Hogner K, Wolff T, Pleschka S, Plog S, Gruber $\mathrm{AD}$, Kalinke U, Walmrath $\mathrm{HD}$, Bodner J, Gattenlohner S, Lewe-Schlosser P, Matrosovich M, Seeger W, Lohmeyer J, Herold $S$ (2013) Macrophage-expressed IFN-beta contributes to apoptotic alveolar epithelial cell injury in severe influenza virus pneumonia. PLoS Pathog 9(2):e1003188. https://doi. org/10.1371/journal.ppat.1003188

13. Fujikura D, Chiba S, Muramatsu D, Kazumata M, Nakayama Y, Kawai T, Akira S, Kida H, Miyazaki T (2013) Type-I interferon is critical for FasL expression on lung cells to determine the severity of influenza. PLoS One 8(2):e55321. https://doi.org/10.1371/jour nal.pone.0055321

14. Teijaro JR, Walsh KB, Cahalan S, Fremgen DM, Roberts E, Scott F, Martinborough E, Peach R, Oldstone MB, Rosen H (2011) Endothelial cells are central orchestrators of cytokine amplification during influenza virus infection. Cell 146(6):980-991. https://doi. org/10.1016/j.cell.2011.08.015 